\author{
UDC 811.111 \\ DOI https://doi.org/10.24919/2308-4863/42-3-13
}

\author{
Iryna KULIKOVA, \\ orcid.org/0000-0002-3495-764X \\ Ph. D. (Education), \\ Senior Lecturer at the English Language Department for Deck Officers \\ Kherson State Maritime Academy \\ (Kherson,Ukraine)Irchik920@gmail.com
}

\title{
RESPONSE CODE AND ITS PRINCIPLE OF USAGE AT THE MARITIME ENGLISH LESSONS
}

\begin{abstract}
The abstract describes such notions as "response code", "maritime English", "teaching and learning processes". Response code is a pedagogical integrative and interactive tool used at any lesson stage and forms to spread out coded information for everyone. Distinguished the problem statement $-Q R$ code is used in educational terms, but it's just a technique in learning process to obtain some professional skills in maritime English. Emphasized the aim is to prove the QR codes can be effectively integrated and applied into teaching practices at the Maritime English lessons not as technology but as pedagogical tool in educational process. Studied many researches devoted to the QR codes: Chaisatien and Akahori, Al-Khalifa, Al-Khalifa. Some of them suggest to use QR codes in guidebooks for students'individual studies where they can find out the information; some as students can ask questions and make comments without embarrassment or suggest the activities using the $Q R$ codes in competitive and collaborative way. Explored advantages of quick response codes they are fast to use to get instant access to encrypted information; they are convenient to consist of large amounts of information in a small image; they are simple and practicable to use. Described the samples of the activities using the QR codes at the lesson stages: "Reflection cube", quiz, "What's the gap?", "Live" QR code. Discovered some teachers' and students' challenges with the QR codes' implementation - is to obtain some time for preparation to create and place $i$, and to have a smartphone and the ability to upload the application. Summed up the involvement of new technologies in the educational process will increase the interest of students in learning, and for teachers can be a convenient form of organization of the educational process.
\end{abstract}

Key words: response code, maritime English, teaching and learning processes.

Ірина КУЛІКОВА, orcid.org/0000-0002-3495-764X кандидат педагогічних наук, стариий викладач кафедри англійської мови в судноводінні Херсонської державної морської академії (Херсон, Україна)Irchik920@gmail.com

\section{КОД ВІДПОВІДІ ТА ЙОГО ПРИНЦИП ВИКОРИСТАННЯ НА ЗАНЯТТЯХ $З$ МОРСЬКОЇ АНГЛІЙСЬКОЇ МОВИ}

У статті описуються такі поняття, як «код відповіді», «морська англійська мова», «процеси навчання». Код відповіді - ие педагогічний інтегративний та інтерактивний інструмент, який використовується на будь-якому етапі заняття будь-якої форми для розповсюдження кодованої інформації для всіх. Порушена проблема полягає в тому, щчо QR-код використовується в освітніх термінах, але иче лише засіб у процесі навчання для отримання визначених професійних навичок у морській англійській мові. Підкреслено, щчо мета полягає в тому, щчоб довести, щзо QR-коди можуть бути ефективно інтегровані та застосовані до практики навчання на заняттях із морськоі англійської мови не як технологї, а як педагогічний інструмент у навчальному процесі. Вивчено багато досліджень, присвячених QR-кодам: Chaisatien i Akahori, Al-Khalifa. Деякі з них пропонують використовувати QR-коди в підручниках для індивідуальних занять студентів, де вони можуть дізнатися інформацію; можуть поставити запитання, коментувати або пропонувати заходи за допомогою QR-кодів у конкурентній та спільній роботі. Вивчені переваги кодів швидкої відповіді, а саме: вони дозволяють миттєво отримати доступ до зашифрованої інформації; їх зручно складати з великого обсягу інформації в маленькому зображенні; вони прості і практичні у використанні. Описані зразки діяльності, використання QR-кодів на етапах уроку: "Куб відображення», вікторина, "Який розрив?», «Живий» QR-код. Виявлені деякі проблеми викладачів та студентів із впровадженням QR-кодів, а саме такі: потрібен час для підготовки до його створення та розміщення, а також треба мати смартфон $і$ можливість завантажити додаток. Висновуємо, що залучення нових технологій до навчального процесу підвищить інтерес студентів до навчання, а для викладачів може стати зручною формою організації навчального процесу.

Ключові слова: код відповіді, морська англійська мова, навчальні прочеси. 
Problem statement. You may see everywhere some graphic pixel codes located on leaflets, in taxis, shops, at stop stations. Such informative images contain much data which can be used not only in everyday life but also in learning process to provide various opportunities for gaining the aim in learning the English language. One of the modern technology which is worth to involve into the educational process at the maritime English lessons is Quick Response (QR), which can be a meaningful and innovative technique at the lesson. A QR code is suggested to be as a graphic image in which certain information, a link to a site or a separate page is encrypted (Law, So, 2010).

The first finding and applying of such coding was in 1994 by the Japanese company in engineering (Traxler, 2009).

It's worth to underline that fact there are so many researches devoted to the mobile learning, but only a few of them belong to the studies the use of QR codes in education. Rikala emphasizes that there is a plenty of ways to use QR code in educational context (Law, So, 2010). As QR codes are unique, they can support learning in different contexts. These contexts can include learning materials which could consist of videos, texts, pictures and more (Rikala, Kankaanranta, 2012). In other words, QR codes can enlarge the learning environment and apply the authentic assignments which are actual for nowadays. Different scholars have their views upon the usage of QR code. With the QR code embedded in the environment, students can obtain contextual or location-aware information (Osawa et al., 2007). QR codes can also enrich paperbased materials so that the material serves different types of learners (Chen et al., 2010). QR codes allow the implementation of systems based on paradigms such as just-in-time and collaborative learning (De Pietro, Frontera, 2012).

We believe the response code is a pedagogical integrative and interactive tool used at any lesson stage and forms to spread out coded information for everyone. We suggest as QR code is used in educational terms, but it's just a technique in learning process to obtain some professional skills in maritime English.

Analysis of the recent researches and publications. It was discovered students use mobile phones and QR codes to send some questions, comments, suggestions to their teachers during the lesson. Susono and Shimomura (2006), Chaisatien and Akahori (2007) and Al-Khalifa (2008). Al-Khalifa (2008) argued that with a QR-code based system students can ask questions and make comments without embarrassment. Law and So suggest the activities using the QR codes in competitive and collaborative way (Law and So, 2010). Lee offers to use QR codes in guide- books for students' individual studies where they can find out the information that is relevant to the matter at hand. They furthermore noticed that QR code activities help integrate digital materials with field trips in a motivating way. In other words, QR codes support a variety of teaching practices. It's worth to mention there wasn't described and studied before the usage of QR code as a learning pedagogical tool in educational process for mariners, its benefits and challenges as for students as for teachers.

Aim. The aim is to define how QR codes can be effectively integrated and applied into teaching practices at the Maritime English lessons not as technology but as pedagogical tool in educational process.

Main body. Quick response code is modified and improved version of the linear barcode, it allows students to obtain and scan any information from the Internet using smartphones. As our category of students (mariners) are usually at distance they have to be involved into learning process, quick response code is an effective tool for this purpose. Mariners sometimes encounter the lack of sources or even the lack of knowledge so the usage of quick response code is rather successful idea at the lessons.

There are some actual advantages of quick response codes:

- they are fast to use to get instant access to encrypted information;

- they are convenient to consist of large amounts of information in a small image;

- they are simple and practicable to use (Osawa, 2009).

With the help of QR-codes teachers may verify the learning process at the Maritime English lessons as follows:

- coding links to homework or class tasks in groups or pairs;

- conducting a quest, tips to each hiding place of which will be encrypted in the form of the corresponding QR-code;

- doing a research;

- creating interactive bulletin board (to use the combination of video, links, QR codes).

All the aforementioned information about QR-code in educational process in different branches may be applied in maritime English successfully too. But as the Maritime English is a special purpose with its unique and professional direction, so it also shall have some specific teaching and learning moments in implementation and usage. Therefore, we distinguish some practical tips for QR-code at the maritime English lessons. This tool may be used at any lesson stage: starter, checking home assignment, presentation, practice, production, evaluation. 
At Starter students may play a game which is not connected closely with the topic or even with marine sphere to warm up and prepare for English speaking environment. "Reflection cube" has a principle Roullete. Each side is coded with some data - questions, pictures for description, audible files etc.

For checking some home assignment it's recommended to make a quiz or mini test for individual work coded it in QR code and finally present the answers on a big screen to make self-correction or feedback. Also it's possible to code the audio files and students may make reports up to heard data.

At Presentation - for new topic vocabulary teacher may code some images for visual understanding, or some audible report or conversation for contextual consideration.

At Practice stage teacher creates a QR Code for each individual question and response. Imagine you are focusing on functional language related to a Ship arrangement situation, you could have each question embedded in each QR Code such as "What is a front part of the ship?", and students scan the codes, write the questions and answers down in their notebooks. Once this is done, you could get students to match question and answers. Students could finally practice asking questions and answering these with a partner. It is a nice activity and students actually enjoy this. Also it's possible to use "What's the gap" activity. Add all missing words into various QR codes, students have a look for the best word to place in a gap but this time the words are embedded within the codes. Students scan the codes and then decided which word is best suited in the gap.

Next activity is suitable for working with a report. It's important to create a $\mathrm{QR}$ code for each line of the report and place these codes around the classroom. Students have to go around the classroom, scan each line to make a report and reorder it in pairs. After that task teacher may ask students - who those people are, topic of report.

Teachers may distribute the QR codes to provide the learners with reading passages in an actual educational setting. Each reading activity is divided into sections: The students use the first QR code to read a short text, with a title given at the top of each page. They use the second code to vote on whether they liked the passage or not. They use the third code to answer some questions. The learners use the first QR code to read a short text that can the involve them. Other two codes that provided additional passages for narrow reading on the same topic. The sequence is repeated for more reading texts. The students are also asked to vote on the titles of reading passages for the next lesson.

During the intensive reading teacher may code some glossary explanations / definitions, images or even links for better understanding the context. QR codes are able to be inserted the text or as additional appendix.

At Production stage teacher can make "Live" QR-code onto relevant website - weather maps to describe current weather at the Port of Rotterdam; Marine Traffic to describe the route from Port A to Port B. Videos with real life situations also can be coded, students decode them and solve the problem, discuss the questions, make alternative ways to prevent the situation etc.

Teacher may make a feedback also using the quick response code. Make a placard with the numbers and corresponding codes. After student answer, ask him to scan the code under appropriate number to know his feedback - "It's great!", "You need to work with your grammar", "Revise topic vocabulary". By the way, this tool is used usually being out of the classroom (on voyage), student may decode the QR code to do some tasks, read some additional info, acquire with the last reports etc.

After each module it's offered to gain the extensive reading of the maritime accident reports. As we know, maritime accident reports are full of realistic professional, geographical, historical data and we recommend to code some additional info about those facts as to enlarge students' interest as to understand and analyze the situation.

Not only teacher may use and implement this tool for her students at the lesson but also students can code some information for peer correction each other beforehand at home or even during the lesson to code their productive activity for another group to comment, analyze, compare, describe, interpret it.

Although, quick response code possesses a big role in learning process but also it provides some challenges as for teachers as for students. Teachers at the preparation stage need some time to create and place it, students require to have a smartphone and the ability to upload the application. But this innovative tool in learning process, namely, at the Maritime English lessons may bring a fresh breath in this process and avoid many problems with the gaps in the subject core and even the expulsion.

Conclusions. The use of QR-codes will diversify the learning process. In addition, the involvement of new technologies in the educational process will increase the interest of students in learning, and for teachers can be a convenient form of organization of the educational process. The findings in this research show the best practice of QR code in pedagogical context for mariners. Further study is worth to devote to the implementation of the QR code in the educational process as the integral part of the lessons. 


\section{BIBLIOGRPAHY}

1. Across the Ocean : coursebook / V. Bondarenko et al. Kherson, 2020. 244 p.

2. Crompton H. A Historical Overview of M-Learning: Toward Learner-Centered Education : handbook. New York : Routledge, 2013. P. 3-14.

3. Koole M. A model for framing mobile learning. Mobile Learning: Transforming the Delivery of Education and Training. Athabasca University Press. Canada. 2009. P. 25-50. URL: https://citeseerx.ist.psu.edu (Last accessed: 21.08.2021).

4. Lucky Voyage : coursebook / T. Malakhivska et al. Kherson, 2019. 272 p.

5. Math Trails / M. Shoaf et al. COMAP, Inc. Lexington, USA. 2004.

6. Traxler J. Current State of Mobile Learning. Mobile Learning : Transforming the Delivery of Education and Training. Athabasca University Press. Canada6 2009. P. 9-24. URL: https://www.researchgate.net (Last accessed: 21.08.2021).

7. Cheung W., Hew K. A review of research methodologies used in studies on mobile handheld devices in K-12 and higher education settings. Australasian Journal of Educational Technology. 2009. Vol. 25. № 2. P. 153-183. URL: https://ajet.org.au (Last accessed: 21.08.2021).

8. Hwang G., Tsai C. Research trends in mobile and ubiquitous learning: A review of publications in selected journals from 2001 to 2010. British Journal of Educational Technology. 2011. Vol. 42. № 4. P. 65-70. URL: https://bera-journals (Last accessed: 21.08.2021).

9. Law C., So S. QR codes in education. Journal of Educational Technology Development and Exchange. 2010. Vol. 3. № 1. P. 85-100. URL: https://www.researchgate.net/journal (Last accessed: 21.08.2021).

10. Scan \& Learn! Use of Quick Response Codes \& Smartphones in a Biology Field Study / J.-K. Lee et al. The American Biology Teacher. 2011. Vol. 73. № 8. P. 485-492. URL: https://www.researchgate.net/journal (Last accessed: 21.08.2021).

11. Outdoor Education Support System with Location Awareness Using RFID and Symbology Tags / N. Osawa et al. Journal of Educational Multimedia and Hypermedia. 2007. Vol. 16. № 4. P. 411-428. URL: https://www.researchgate.net (Last accessed: 21.08.2021).

\section{REFERENCES}

1. Across the Ocean: coursebook / V. Bondarenko et al. Kherson, 2020. 244 p.

2. Crompton, H. A Historical Overview of M-Learning : Toward Learner-Centered Education: handbook. New York : Routledge, 2013. P. 3-14.

3. Koole, M. L. A model for framing mobile learning. Mobile Learning: Transforming the Delivery of Education and Training. Athabasca University Press. Canada, 2009. P. 25-50. URL: https://citeseerx.ist.psu.edu (Last accessed: 21.08.2021).

4. Lucky Voyage: coursebook / T. Malakhivska et al. Kherson. 2019. 272 p.

5. Math Trails / M. M. Shoaf et al. COMAP, Inc. Lexington, USA. 2004.

6. Traxler, J. Current State of Mobile Learning. Mobile Learning: Transforming the Delivery of Education and Training. Athabasca University Press. Canada. 2009. P. 9-24. URL: https://www.researchgate.net (Last accessed: 21.08.2021).

7. Cheung, W. S., and Hew, K. F. A review of research methodologies used in studies on mobile handheld devices in K-12 and higher education settings. Australasian Journal of Educational Technology. 2009. Vol. 25. № 2. P. 153-183. URL: https://ajet.org.au (Last accessed: 21.08.2021).

8. Hwang, G., and Tsai, C. Research trends in mobile and ubiquitous learning: A review of publications in selected journals from 2001 to 2010. British Journal of Educational Technology. 2011. Vol. 42, № 4 P. 65-70. URL: https://bera-journals (Last accessed: 21.08.2021).

9. Law, C., and So, S. QR codes in education. Journal of Educational Technology Development and Exchange. 2010. Vol. 3. № 1. P. 85-100. URL: https://www.researchgate.net/journal (Last accessed: 21.08.2021).

10. Lee, J.-K. et al. Scan \& Learn! Use of Quick Response Codes \& Smartphones in a Biology Field Study. The American Biology Teacher. 2011. Vol. 73. № 8. P. 485-492. URL: https://www.researchgate.net/journal (Last accessed: 21.08.2021).

11. Osawa, N. et al. Outdoor Education Support System with Location Awareness Using RFID and Symbology Tags. Journal of Educational Multimedia and Hypermedia. 2007. Vol. 16. № 4. P. 411-428. URL: https://www.researchgate.net (Last accessed: 21.08.2021). 